\title{
Prevalence and Incidence of Yellow Dwarf Viruses Across a Climatic Gradient: A Four-Year Field Study in Southeastern Australia
}

\author{
Narelle Nancarrow ${ }^{\dagger}$ and Mohammad Aftab, Agriculture Victoria, Horsham, VIC 3400, Australia; Angela Freeman and Brendan Rodoni, \\ Agriculture Victoria, AgriBio, Centre for AgriBioscience, Bundoora, VIC 3083, Australia; and Grant Hollaway and Piotr Trębicki, Agricul- \\ ture Victoria, Horsham, VIC 3400, Australia
}

\begin{abstract}
Yellow dwarf viruses (YDVs) form a complex of economically important pathogens that affect cereal production worldwide, reducing yield and quality. The prevalence and incidence of YDVs including barley yellow dwarf viruses (BYDV-PAV and BYDV-MAV) and cereal yellow dwarf virus (CYDV-RPV) in cereal fields in Victoria, Australia were measured. As temperature decreases and rainfall increases from north to south in Victoria, fields in three geographical regions were evaluated to determine potential differences in virus prevalence and incidence across the weather gradient. Cereal samples randomly collected from each field during spring for four consecutive years (2014-2017) were tested for BYDV-PAV, BYDV-MAV, and CYDV-RPV using tissue blot

immunoassay. BYDV-PAV was the most prevalent YDV species overall and had the highest overall mean incidence. Higher temperature and lower rainfall were associated with reduced prevalence and incidence of YDVs as the northern region, which is hotter and drier, had a 17-fold decrease in virus incidence compared with the cooler and wetter regions. Considerable year-to-year variation in virus prevalence and incidence was observed. This study improves our understanding of virus epidemiology, which will aid the development of more targeted control measures and predictive models. It also highlights the need to monitor for YDVs and their vectors over multiple years to assess the level of risk and to make more informed and appropriate disease management decisions.
\end{abstract}

During 2014-2015, around 18 million ha of land was sown to cereals in Australia, producing approximately 23 million $\mathrm{t}$ of wheat, 8 million $t$ of barley, and 1 million $t$ of oats (ABARES 2017). Food production is constantly threatened by a range of abiotic factors such as temperature, water, light, and nutrition stress (Bos and Parlevliet 1995; Oerke 2006) and biotic factors, such as pests and diseases including weeds, animals, fungi, and viruses (Luck et al. 2011; Murray and Brennan 2009, 2010; Oerke 2006). Although pest and disease management has contributed to increasing food production, approximately $10-16 \%$ of global crop production is still lost annually to plant pathogens (Oerke 2006; Strange and Scott 2005). Vector-borne plant viruses are particularly challenging to manage due to the complex interactions between host plants, viruses, vectors, and the environment (Castle et al. 2009; Jones 2016; Trębicki et al. 2017a). Additionally, when infection occurs, little can be done to eliminate the virus on a field scale. To prevent, control, or manage these viruses, it is important to understand their biology, epidemiology, and ecology.

Yellow dwarf viruses (YDVs) are the most economically important viruses affecting cereals worldwide (Plumb 1983), reducing yield and quality (McKirdy et al. 2002). YDVs have a wide host range, infecting wheat (Triticum aestivum), barley (Hordeum vulgare), oats (Avena sativa), and many other grass species in the family Poaceae. There are currently 10 recognized species of YDV within the family Luteoviridae (Adams et al. 2016), consisting of Barley yellow dwarf virus (BYDV), Cereal yellow dwarf virus (CYDV), and Maize yellow dwarf virus (MYDV). Five species have been assigned to the genus Luteovirus (BYDV-kerII, BYDV-kerIII, BYDV-MAV, BYDV-PAS, and BYDV-PAV), three have been assigned to the genus Polerovirus (CYDV-RPS, CYDV-RPV, and MYDV-RMV), and two are yet to be assigned to any genus (BYDV-GPV and BYDV-SGV). Four of these species (BYDV-PAV, BYDV-MAV, CYDV-RPV, and

${ }^{\dagger}$ Corresponding author: N. Nancarrow;

E-mail: narelle.nancarrow@ecodev.vic.gov.au

Funding: This study was funded by the Grains Research and Development Corporation (GRDC) and Agriculture Victoria, Australia.

Accepted for publication 18 May 2018

C 2018 The American Phytopathological Society
MYDV-RMV) have been found in eastern Australia (Sward and Lister 1987, 1988) with BYDV-PAV the most commonly detected YDV in Victoria (Sward and Lister 1987, 1988).

YDVs are phloem-limited and are transmitted by several aphid species in a persistent, circulative manner (Irwin and Thresh 1990; Miller and Rasochová 1997). The most common aphid vectors of YDV found in Victoria are the bird cherry-oat aphid (Rhopalosiphum padi) and the corn aphid (Rhopalosiphum maidis) (Smith and Plumb 1981). Symptoms of YDV infection can vary depending on the host species but generally include stunted growth, yellowing (in barley and wheat) or reddening (in oats and wheat) of leaves, delayed heading, and reduced yields (Miller and Rasochová 1997), with yield losses due to YDV infection increasing with every $1 \%$ increase in incidence (Banks et al. 1995; McKirdy et al. 2002; Smith and Sward 1982). Although distinct symptoms may occur in cereals, infection can also be present without visible symptoms, and many infected native grasses are asymptomatic (Guy et al. 1987; Malmstrom et al. 2017). The mechanisms associated with YDV infection in the field are complex and influenced by many factors. In Australia, wild grasses, perennial pasture grasses, and volunteer cereals play a significant role as virus and vector reservoirs during summer and between growing seasons (McKirdy and Jones 1997). Temperature and wind through their effects on aphid activity also play an important part in YDV epidemics (Thackray et al. 2009). For example, the number of aphids that survive a southern Australian summer has been shown to decrease with increasing number of days with a maximum temperature greater than or equal to $36^{\circ} \mathrm{C}$ (De Barro 1991).

Typically, in western Victoria (Australia), temperature decreases and rainfall increases from north to south. In this study, it was hypothesized that the prevalence (proportion of fields with infected plants) and incidence (proportion of infected plants within a field) of YDV would vary with the weather gradient. This would result in more YDV infection in the southwest of the state, which is relatively wet with mild temperatures, than the northwest of the state, which is drier and hotter. This hypothesis was based on the observation that YDVs are more prevalent and damaging in regions where annual rainfall exceeds $500 \mathrm{~mm}$ in southern Australia (De Barro 1991; Henry et al. 1992), where more grasses survive over summer, and therefore vector and virus reservoirs are more likely to be maintained between growing seasons. The absence of up-to-date virus monitoring was identified as a critical knowledge gap in a review of YDVs and their vectors in Australia (Parry et al. 2012). Information 
about YDV occurrence in Victoria has not been updated for decades. This 4-year study of YDVs from three distinct regions within Victoria in southeastern Australia provides key information about the prevalence and incidence of YDVs. It also highlights the importance of understanding virus epidemiology in order to predict the occurrence and severity of YDVs, improve management, and reduce input costs.

\section{Materials and Methods}

Field selection. Fields located in the major cereal production area from northwestern to southwestern Victoria, Australia were sampled during the spring (September-October) of 2014, 2015, 2016, and 2017. Three geographical regions of western Victoria were targeted: the Mallee $\left(23.9^{\circ} \mathrm{C}\right.$ mean maximum temperature, $296 \mathrm{~mm}$ mean annual rainfall), the Wimmera $\left(22.2^{\circ} \mathrm{C}\right.$ mean maximum temperature, $371 \mathrm{~mm}$ mean annual rainfall), and the South West $\left(19.2^{\circ} \mathrm{C}\right.$ mean maximum temperature, $617 \mathrm{~mm}$ mean annual rainfall) (Fig. 1). In 2014, samples (tillers) were collected from 12 wheat and 8 barley fields from the Wimmera and South West. In 2015, samples were collected from 11 wheat, 9 barley, and 1 oat field from the Mallee, Wimmera, and South West. In 2016, 9 wheat, 11 barley, and 1 oat field were sampled from the Mallee, Wimmera, and South West. In 2017, 12 wheat and 9 barley fields were sampled from the Mallee, Wimmera, and South West. The Mallee was not included in the study in 2014 but was included in following years. No oat fields were sampled in 2014 or 2017, but one was sampled in each of 2015 and 2016. Within each region and year, fields were randomly selected and were at least $10 \mathrm{~km}$ apart. Field locations were recorded using Global Positioning System (GPS).

Sample collection. Within each field, a total of 100 tillers were collected, with one tiller collected at each 10-m interval in a zigzag design (Trębicki et al. 2010), starting at least $10 \mathrm{~m}$ from the edge of the field. All tillers were placed into a plastic bag and stored at $4{ }^{\circ} \mathrm{C}$ until processed.

Sample blotting. To increase processing efficiency, the 100 tillers collected from a field were separated into 10 groups, with each group of 10 tillers wrapped with Parafilm into a bundle. Each bundle of tillers was blotted onto four individual nitrocellulose membranes (Whatman Protran, $0.45 \mu \mathrm{m}$ ) to enable testing for four different viruses. To blot tiller sap onto a membrane, the top of the bundle was cut using a scalpel and immediately blotted onto the membrane.

Tissue blot immunoassay (TBIA). TBIA was performed as described by Trębicki et al. (2017b), using polyclonal antibodies for BYDV-PAV (AS-0235), BYDV-MAV (AS-0540), and CYDV-RPV (AS-0539) (DSMZ, Germany). Membranes and previously confirmed positive control blots were placed in plastic containers and washed twice with phosphate buffered saline-Tween solution (PBS-Tween) $\left(0.02 \mathrm{M} \mathrm{K}_{2} \mathrm{HPO}_{4}, 0.15 \mathrm{M} \mathrm{NaCl}, \mathrm{pH} 7.4,0.05 \%\right.$ Tween 20$)$ for 3 min each time while shaking. The membranes were blocked by incubating for $1 \mathrm{~min}$ with $1 \mu \mathrm{g} / \mathrm{ml}$ polyvinyl alcohol (PVA) while shaking and were washed twice with PBS-Tween as described. Membranes were incubated with primary antibodies that had previously been diluted $1 / 2,000$ in healthy wheat extract to reduce background reactivity as described by Freeman et al. (2013) for $1 \mathrm{~h}$ with shaking and washed with PBS-Tween. This was followed by a 1-h incubation with goat antirabbit secondary antibody conjugated to alkaline phosphatase (Invitrogen, USA) diluted 1/2,000 in conjugate buffer (PBS-Tween containing $2 \%$ poly vinyl pyrrolidine and $0.2 \%$ bovine serum albumin) with shaking and washing with PBS Tween as described. Membranes were incubated with substrate buffer $\left(0.1 \mathrm{M}\right.$ Tris, $0.1 \mathrm{M} \mathrm{NaCl}$, and $\left.5 \mathrm{mM} \mathrm{MgCl}_{2}, \mathrm{pH} 9.5\right)$ containing $14 \mathrm{mg}$ nitrotetrazolium blue chloride and $7 \mathrm{mg}$ 5-bromo-4-chloro3 -indolyl phosphate per 40-ml substrate buffer with shaking for 30-60 min. The reaction was stopped by washing the membranes

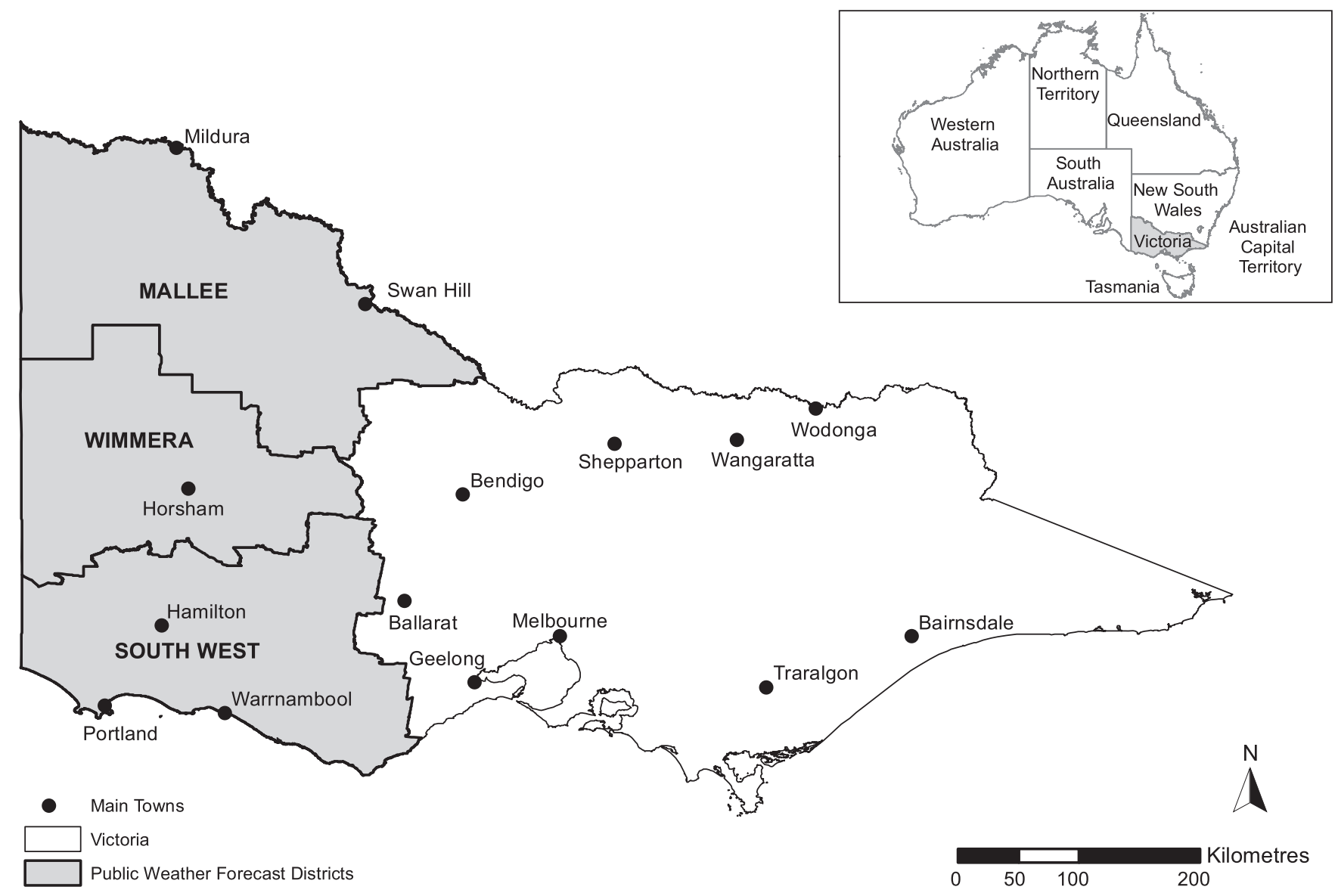

Fig. 1. Map of the three geographical regions (Mallee, Wimmera, and South West) representing the weather gradient of western Victoria where cereal fields were sampled and tested for BYDV-PAV, CYDV-RPV, and BYDV-MAV during 2014-2017. 
with distilled water 3 times. The membranes were air-dried on paper towels. All blots were examined for dark purple staining in the phloem using a dissecting microscope. The number of positive (purple staining) and negative (no purple staining) tillers within each bundle was recorded. The number and percentage of positive tillers within a field was then calculated.

Weather data. Temperature and rainfall records from Hopetoun airport (Station No. 77010), Horsham aerodrome (Station No. 79100), and Hamilton airport (Station No. 90173) were obtained from the Bureau of Meteorology (BOM) website (www.bom.gov. $\mathrm{au}$ ) to represent the Mallee, Wimmera, and South West regions, respectively. Long-term mean rainfall and mean maximum temperature for the months of January-June and July-December for each region were calculated using records from 2005-2017. Daily maximum temperatures were used to calculate the number of days with maximum temperature $\geq 36^{\circ} \mathrm{C}$ for each region.

Data analysis. YDV prevalence (\%) was calculated using the formula [number of fields in which at least one YDV species (BYDVPAV, CYDV-RPV, or BYDV-MAV) was detected/number of fields sampled] * 100. Prevalence (\%) of BYDV-PAV, CYDV-RPV, and BYDV-MAV was calculated using the formula [number of fields with infected plants/number of fields sampled] * 100, while incidence (\%) of BYDV-PAV, CYDV-RPV, and BYDV-MAV in each field was calculated using the formula [number of infected plants/ number of plants tested] $* 100$. Data from 2014 were excluded from the dataset when comparing overall virus prevalence and incidence in the Mallee, Wimmera, and South West because samples were not collected from the Mallee in 2014. Otherwise, data from all fields were used to calculate all other percentages of prevalence and incidence reported. In addition, Spearman's rank correlation was used to evaluate relationships between virus incidence and weather conditions, specifically rainfall and temperature. Mean BYDV-PAV incidence for each region in each year was correlated against total rainfall, mean maximum temperature, and the number of days with maximum temperature $\geq 36^{\circ} \mathrm{C}$ recorded at the Hopetoun (Mallee), Horsham (Wimmera), and Hamilton (South West) (Victoria, Australia) weather stations during January-June and July-December in the year preceding the growing season and January-June in the year of the growing season. Means, standard error of the means (SEM), and Spearman's rank correlation coefficients $\left(r_{s}\right)$ were obtained using GenStat 14th Edition (VSN International Ltd., Hemel Hempstead, UK). Graphs were produced in SigmaPlot.
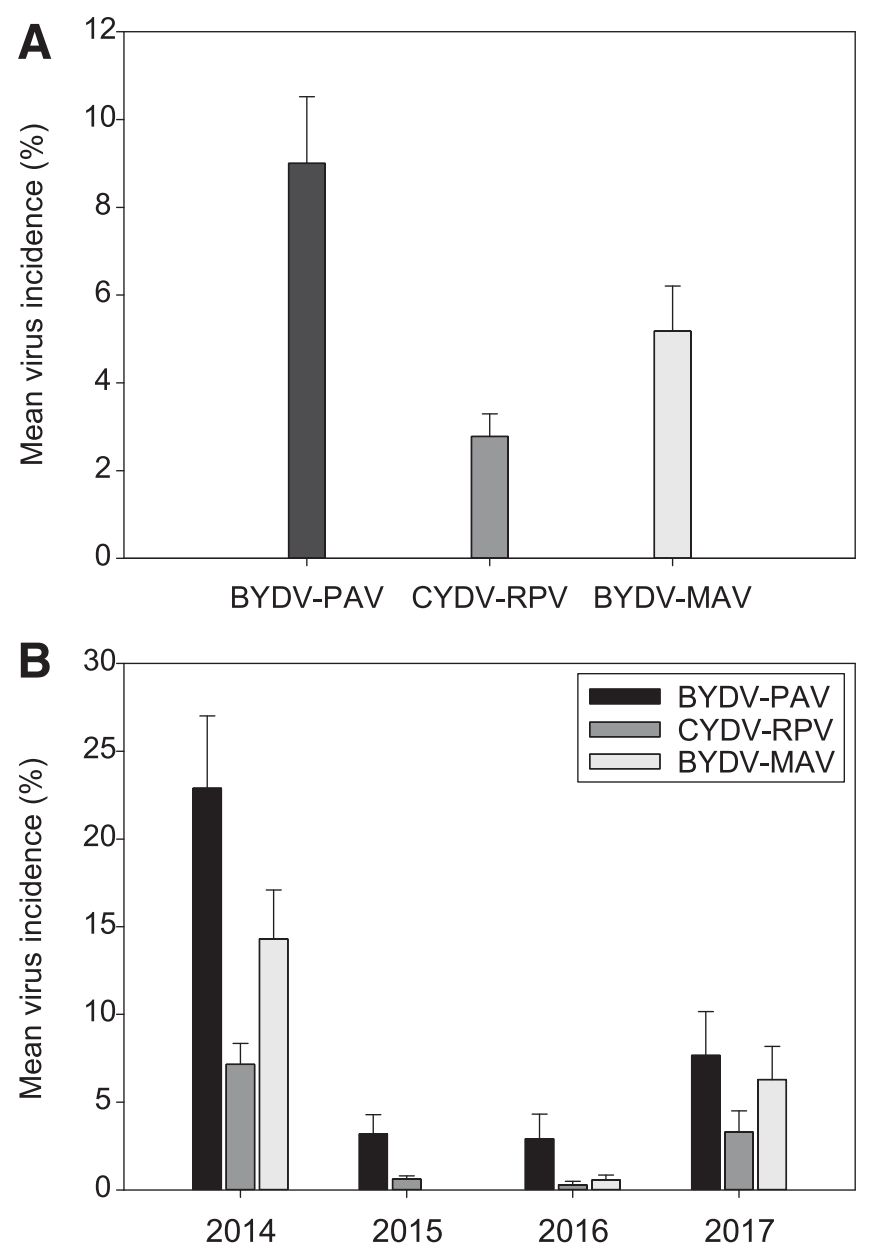

Fig. 2. Mean incidence of BYDV-PAV, CYDV-RPV, and BYDV-MAV in cereal fields in Victoria A, overall during 2014-2017 ( $n=83)$; and B, in $2014(n=20), 2015(n=21)$, $2016(n=21)$, and $2017(n=21)$ individually. Error bars represent standard errors of means.

Table 1. Rainfall (mm) and mean maximum temperature $\left({ }^{\circ} \mathrm{C}\right)$ (half-yearly) in 2013, 2014, 2015, 2016, and 2017, long-term (half-yearly) mean rainfall (mm) and mean maximum temperatures $\left({ }^{\circ} \mathrm{C}\right)$, and number of days with maximum temperature $\geq 36^{\circ} \mathrm{C}$ for the Mallee, Wimmera, and South West regions of Victoria

\begin{tabular}{|c|c|c|c|c|c|c|c|}
\hline \multirow[b]{2}{*}{ Rainfall (mm) } & \multirow[t]{2}{*}{ Year } & \multicolumn{2}{|c|}{ Mallee } & \multicolumn{2}{|c|}{ Wimmera } & \multicolumn{2}{|c|}{ South West } \\
\hline & & Jan-Jun & Jul-Dec & Jan-Jun & Jul-Dec & Jan-Jun & Jul-Dec \\
\hline & 2013 & 93 & 123 & 148 & 251 & 166 & 392 \\
\hline & 2014 & 130 & 68 & 162 & 93 & 289 & 200 \\
\hline & 2015 & 138 & 77 & 145 & 85 & 267 & 206 \\
\hline & 2016 & 163 & 267 & 174 & 288 & 308 & 531 \\
\hline & 2017 & 163 & 203 & 182 & 249 & 291 & 393 \\
\hline Long-term mean rainfall (mm) & $2005-2017$ & $\begin{array}{c}\text { Jan-Jun } \\
141\end{array}$ & $\begin{array}{l}\text { Jul-Dec } \\
161\end{array}$ & $\begin{array}{l}\text { Jan-Jun } \\
178\end{array}$ & $\begin{array}{l}\text { Jul-Dec } \\
201\end{array}$ & $\begin{array}{l}\text { Jan-Jun } \\
255\end{array}$ & $\begin{array}{l}\text { Jul-Dec } \\
339\end{array}$ \\
\hline \multirow[t]{6}{*}{ Mean maximum temperature $\left({ }^{\circ} \mathrm{C}\right)$} & & Jan-Jun & Jul-Dec & Jan-Jun & Jul-Dec & Jan-Jun & Jul-Dec \\
\hline & 2013 & 25.9 & 22.8 & 24.5 & 20.3 & 22.3 & 17.4 \\
\hline & 2014 & 25.9 & 23.6 & 24.4 & 21.8 & 22 & 18.8 \\
\hline & 2015 & 24.6 & 23.6 & 23.1 & 22.3 & 20.3 & 19.2 \\
\hline & 2016 & 25.7 & 21.3 & 24.2 & 19.2 & 21.4 & 16.9 \\
\hline & 2017 & 25.5 & 23.1 & 23.9 & 21 & 21.3 & 18.1 \\
\hline \multirow[t]{2}{*}{ Long-term mean maximum temperature $\left({ }^{\circ} \mathrm{C}\right)$} & $2005-2017$ & Jan-Jun & Jul-Dec & Jan-Jun & Jul-Dec & Jan-Jun & Jul-Dec \\
\hline & & 25.3 & 22.7 & 23.8 & 20.8 & 21.2 & 18 \\
\hline \multirow{6}{*}{$\begin{array}{l}\text { Number of days with maximum } \\
\text { temperature } \geq 36^{\circ} \mathrm{C}\end{array}$} & & \multicolumn{2}{|c|}{ Jan-Dec } & \multicolumn{2}{|c|}{ Jan-Dec } & \multicolumn{2}{|c|}{ Jan-Dec } \\
\hline & 2013 & \multicolumn{2}{|c|}{36} & \multicolumn{2}{|c|}{24} & \multicolumn{2}{|c|}{11} \\
\hline & 2014 & \multicolumn{2}{|c|}{35} & \multicolumn{2}{|c|}{22} & \multicolumn{2}{|c|}{12} \\
\hline & 2015 & \multicolumn{2}{|c|}{41} & \multicolumn{2}{|c|}{26} & \multicolumn{2}{|c|}{13} \\
\hline & 2016 & \multicolumn{2}{|c|}{30} & \multicolumn{2}{|c|}{18} & \multicolumn{2}{|c|}{5} \\
\hline & 2017 & \multicolumn{2}{|c|}{28} & \multicolumn{2}{|c|}{18} & \multicolumn{2}{|c|}{5} \\
\hline
\end{tabular}




\section{Results}

Weather data. The mean annual maximum temperature over the duration of this study (2013-2017) was highest in the Mallee $\left(24.2^{\circ} \mathrm{C}\right.$ average), followed by the Wimmera $\left(22.5^{\circ} \mathrm{C}\right.$ average $)$ and the South West $\left(19.8^{\circ} \mathrm{C}\right.$ average). Total rainfall for that period was lowest in the Mallee (1,425 mm total), higher in the Wimmera (1,778 $\mathrm{mm}$ total), and highest in the South West $(3,044 \mathrm{~mm}$ total). Across the three regions, rainfall in the first half of the year was $55 \mathrm{~mm}$ higher than the long-term mean in 2013, $3 \mathrm{~mm}$ lower in 2014, $8 \mathrm{~mm}$ lower in 2015, $24 \mathrm{~mm}$ higher in 2016, and $21 \mathrm{~mm}$ higher in 2017; however, rainfall in the second half of the year was $21 \mathrm{~mm}$ higher than the mean in 2013, $114 \mathrm{~mm}$ lower in 2014, $111 \mathrm{~mm}$ lower in 2015, $128 \mathrm{~mm}$ higher in 2016, and $48 \mathrm{~mm}$ higher in 2017 (Table 1). In total, over the period of 2013-2017, and in each of those years individually, there were more days with a maximum temperature $\geq 36^{\circ} \mathrm{C}$ in the Mallee (170 total) than the Wimmera (108 total) and the South West (46 total) (Table 1).

Virus prevalence and incidence. During this 4-year study, 83 cereal fields were tested for BYDV-PAV, CYDV-RPV, and BYDVMAV infection, and approximately 24,900 TBIA tests were conducted. YDVs were detected in $75 \%$ of fields with a maximum incidence of $58 \%$. The prevalence of YDV varied between years, with YDVs detected in $100 \%$ of fields in 2014 compared with 76,48 , and $76 \%$ of fields in 2015, 2016, and 2017, respectively. The highest virus incidence occurred in 2014, with mean virus incidence reaching $23 \%$ in $2014,3 \%$ in $2015,3 \%$ in 2016 , and $8 \%$ in 2017 , while the maximum virus incidence in an individual field was $58 \%$ in $2014,22 \%$ in 2015 , $29 \%$ in 2016 , and $42 \%$ in 2017.

Overall, BYDV-PAV was the most prevalent of the three YDV species, detected in $70 \%$ of fields, while CYDV-RPV and BYDVMAV were detected in $55 \%$ and $46 \%$ of fields, respectively. The overall mean incidence of BYDV-PAV $(9 \%)$ was higher than that of CYDV-RPV (3\%) and BYDV-MAV (5\%) (Fig. 2A). Likewise, the maximum incidence of BYDV-PAV $(58 \%)$ was higher than that of CYDV-RPV (24\%) and BYDV-MAV (39\%); furthermore, although CYDV-RPV was present at more sites than BYDV-MAV, BYDV-MAV had a higher mean and maximum incidence than CYDV-RPV. Mean incidence of BYDV-PAV was also higher than that of CYDV-RPV and BYDV-MAV in each individual year (Fig. 2B).

To compare overall virus prevalence and incidence across the Mallee, Wimmera, and South West regions, data from 2014 were excluded, as samples were not collected from the Mallee in 2014. Throughout 2015-2017, YDVs were detected in fewer fields in the Mallee $(36 \%)$ than the Wimmera $(81 \%)$ and South West $(85 \%)$ (Table 2), and the maximum YDV incidence within a field was lower in the Mallee $(7 \%)$ than in the Wimmera $(42 \%)$ and South West (33\%). Additionally, BYDV-PAV, CYDV-RPV, and BYDV-MAV were each detected in fewer fields and with lower mean incidence in the Mallee than in the Wimmera and South West (Table 2, Fig. 3). However, prevalence and mean incidence of BYDV-PAV, CYDV-RPV, and BYDV-MAV were similar between the Wimmera and South West, except that the mean incidence of CYDV-RPV was slightly higher in the South West (3\%) than in the Wimmera (1\%) (Table 2, Fig. 3). There were no clear trends in virus prevalence or incidence between the Wimmera and South West when comparing data from year to year (Table 3, Fig. 4).

The mean incidence of BYDV-PAV, CYDV-RPV, or BYDVMAV did not exceed $1 \%$ in the Mallee in any year of this study (Fig. 4). BYDV-MAV was only detected in one field in the Mallee throughout this study and was not detected in any fields in 2015. CYDV-RPV was not detected in the Mallee or South West in 2016, and BYDV-MAV was not detected in the Wimmera or South West in 2015. Mean incidence of CYDV-RPV and BYDV-MAV was low $(<2 \%)$ in each region in 2015 and 2016 (Fig. 4).

Overall, each YDV species was detected in more wheat than barley fields, with BYDV-PAV present in $76 \%$ of wheat and $60 \%$ of barley fields, CYDV-RPV present in $63 \%$ of wheat and $46 \%$ of barley fields, and BYDV-MAV present in $52 \%$ of wheat and $37 \%$ of barley fields. There was also a higher mean incidence of each of the three YDV species in wheat than in barley, with a mean incidence of BYDV-PAV of $12 \%$ in wheat and $4 \%$ in barley, an incidence of CYDV-RPV of $3 \%$ in wheat and $2 \%$ in barley, and an incidence of BYDV-MAV of 7\% in wheat and 3\% in barley (Fig. 5).

Mean BYDV-PAV incidence was positively correlated with rainfall $\left(r_{s}=0.63\right)$ (Fig. 6A) and negatively correlated with mean maximum temperature $\left(r_{s}=-0.64\right)$ (Fig. 6B) and number of days with maximum temperature $\geq 36^{\circ} \mathrm{C}\left(r_{s}=-0.68\right)$ (Fig. 6C) during JulyDecember in the year preceding the growing season.

\section{Discussion}

In this study, we investigated the prevalence and incidence of YDVs across the Victorian grain belt in southeastern Australia. We hypothesized that YDV infection would vary across the state with changing rainfall and temperature (Table 1), resulting in varying soil moisture levels and therefore host availability for the virus and vector, particularly during summer. As temperature decreased and rainfall increased from the north to the south of the state, the Mallee, with higher temperature and lower rainfall, recorded lower prevalence and incidence of YDV than the Wimmera and South West; however, there were no overall differences between the Wimmera and South West. Higher temperature and lower rainfall, which is characteristic of the Mallee when compared with the other regions investigated, were correlated with reduced virus incidence (Fig. 6). In each year of the study, the highest YDV prevalence and incidence was recorded in either the Wimmera or South West.

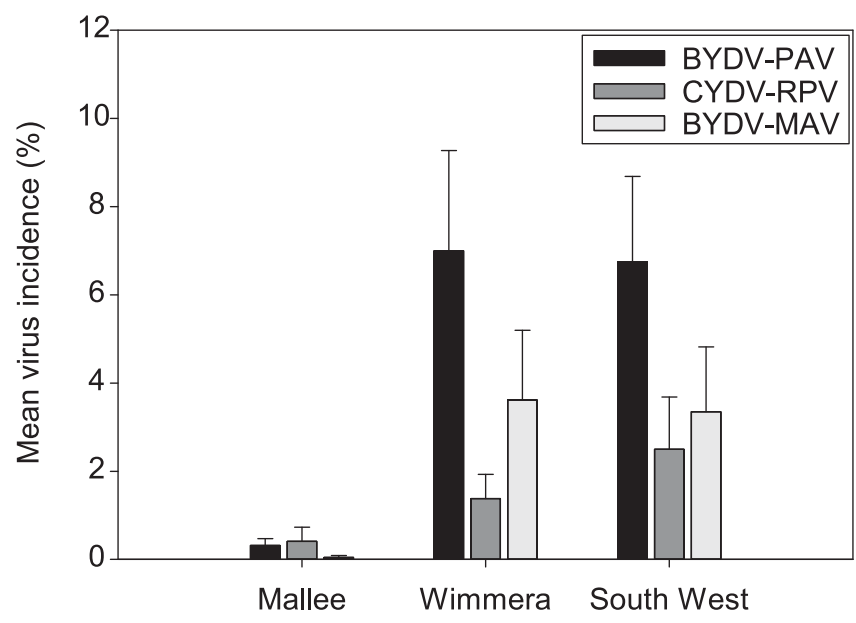

Fig. 3. Mean incidence of BYDV-PAV, CYDV-RPV, and BYDV-MAV in cereal fields in the Mallee $(n=22)$, Wimmera $(n=21)$, and South West $(n=20)$ regions of Victoria during 2015-2017. Error bars represent standard errors of means.

Table 2. Prevalence of BYDV-PAV, CYDV-RPV, BYDV-MAV, and YDV in cereal fields in the Mallee, Wimmera, and South West regions of Victoria during 2015-2017

\begin{tabular}{|c|c|c|c|c|c|}
\hline Region & Number of fields sampled & BYDV-PAV (\%) & CYDV-RPV (\%) & BYDV-MAV (\%) & YDV $(\%)$ \\
\hline Mallee & 22 & 23 & 14 & 5 & 36 \\
\hline Wimmera & 21 & 81 & 52 & 48 & 81 \\
\hline South West & 20 & 80 & 60 & 40 & 85 \\
\hline
\end{tabular}


In this study, YDVs were more prevalent and occurred with higher incidence than had previously been reported in cereal fields in Victoria (Sward and Lister 1987), indicating that the impact of YDVs on cereals in Victoria may have been underestimated. Given that yield losses due to YDV infection have been shown to increase with every $1 \%$ increase in YDV incidence (Banks et al. 1995; McKirdy et al. 2002; Smith and Sward 1982), yield losses in Victorian cereal fields due to YDV infection are also likely to be higher than previously estimated. Sward and Lister (1987) reported that BYDV was detected in 38\% of wheat fields in 1984; however, throughout 2014-2017, BYDV-PAV was detected in $70 \%$ of fields, which was almost twice as many as reported just over 30 years ago. Sward and Lister (1987) also estimated a mean BYDV incidence of $2 \%$ in 1984; however, the mean incidence of BYDV-PAV was 9\% throughout 2014-2017, which is more than four times as high, even though temperature and rainfall conditions in 1983-1984 were conducive to the development of virus infection (i.e., cool temperature and high rainfall). Changes in climate and other factors, including farming practices, since 1984 may have contributed to the increased YDV infection reported in this study. Since 1970 in western Victoria, annual mean temperature has risen $0.15-0.3^{\circ} \mathrm{C}$ per decade, and annual rainfall has fallen 5-20 mm per decade, while $\mathrm{CO}_{2}$ levels have risen from 338 ppm in 1980 to 406 ppm in 2017 (BOM; NOAA Earth System Research Laboratory). Although this study shows lower YDV

Table 3. Prevalence of BYDV-PAV, CYDV-RPV, and BYDV-MAV in cereal fields in the Mallee, Wimmera, and South West regions of Victoria in 2014, 2015, 2016, and 2017

\begin{tabular}{|c|c|c|c|c|c|}
\hline Year & Region & Number of fields sampled & BYDV-PAV (\%) & CYDV-RPV (\%) & BYDV-MAV (\%) \\
\hline \multirow[t]{3}{*}{2014} & Mallee & 0 & $\mathrm{NT}^{\mathrm{a}}$ & NT & NT \\
\hline & Wimmera & 12 & 100 & 100 & 92 \\
\hline & South West & 8 & 100 & 100 & 100 \\
\hline \multirow[t]{3}{*}{2015} & Mallee & 8 & 38 & 25 & 0 \\
\hline & Wimmera & 7 & 71 & 43 & 0 \\
\hline & South West & 6 & 83 & 83 & 0 \\
\hline \multirow[t]{3}{*}{2016} & Mallee & 7 & 14 & 0 & 0 \\
\hline & Wimmera & 7 & 71 & 29 & 43 \\
\hline & South West & 7 & 57 & 0 & 14 \\
\hline \multirow[t]{3}{*}{2017} & Mallee & 7 & 14 & 14 & 14 \\
\hline & Wimmera & 7 & 100 & 86 & 100 \\
\hline & South West & 7 & 100 & 100 & 100 \\
\hline
\end{tabular}

${ }^{a} \mathrm{NT}=$ not tested.
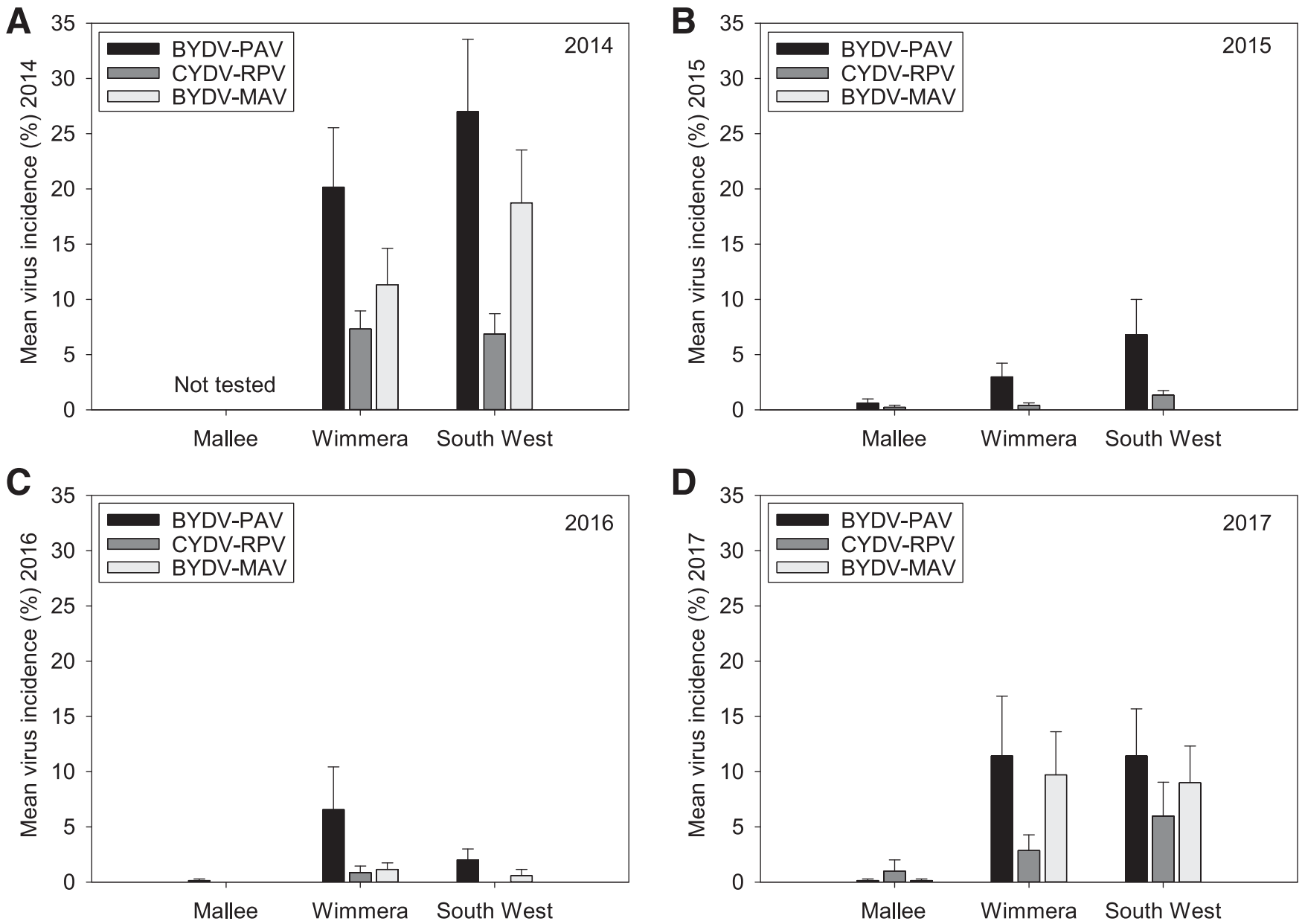

Fig. 4. Mean incidence of BYDV-PAV, CYDV-RPV, and BYDV-MAV in cereal fields in the Mallee ( $n=0$ in 2014, 8 in 2015, and 7 in 2016 and 2017 ), Wimmera ( $n=12$ in 2014 and 7 in 2015, 2016, and 2017), and South West ( $n=8$ in 2014, 6 in 2015, and 7 in 2016 and 2017) regions of Victoria in A, 2014; B, 2015; C, 2016; and D, 2017. Error bars represent standard errors of means. 
incidence under hotter and drier conditions as a result of suboptimal conditions for the virus and vector to persist during the summer months, increased temperature early in the growing season and increased $\mathrm{CO}_{2}$ have been shown to promote virus replication (Nancarrow et al. 2014; Trębicki et al. 2015), increased virus titer can affect transmission efficiency (Gray et al. 1991; Jiménez-Martínez and BosquePérez 2004), and elevated $\mathrm{CO}_{2}$ increases virus incidence in field experiments (Trębicki et al. 2017b). This suggests that it is possible that changes in climate since 1984 may have contributed to the increased virus infection observed during 2014-2017 in comparison with 1984 and highlights the complexity and intricacy of the interactions within virus-vector-plant-environment systems and the complications involved in predicting and modeling these interactions and relationships.

The year-to-year variation observed in this study highlights the importance of regular YDV monitoring and assessment over multiple years to capture the variation between years and obtain a realistic picture of YDV occurrence. Although such variation can be complex and difficult to define, it is influenced by differences in environmental conditions, availability of virus reservoirs, aphid populations, aphid activity, long-distance migration of aphids, the abundance of natural enemies, and the interactions among these factors. In each year of the study, there was less YDV infection in the Mallee than in the Wimmera and South West, but there were no overall differences between the Wimmera and South West, suggesting that there may be thresholds at which conditions such as temperature and rainfall, their interactions, and their effects on aphid populations, activity, and natural enemies start to level out. The 'just above' average rainfall across the three regions during the latter half of 2013, combined with average rainfall in the early months of 2014 (Table 1), may have led to an increase in survival of wild grasses, perennial pasture grasses, and volunteer cereals between the 2013 and 2014 growing seasons (i.e., a green bridge), thus providing a refuge for the aphid vector and the virus, resulting in the high virus incidence observed in 2014. In contrast, conditions in western Victoria were dry and hot during the latter half of 2014 and 2015 (Table 1), and these weather conditions are likely to have limited the availability of a green bridge to act as aphid and virus reservoirs, leading to the low virus incidences of 2015 and 2016.

Hawkes and Jones (2005) reported that there were few differences in overall YDV infection in over-summering grasses and volunteer cereals between rainfall zones of the grain-belt of Western Australia, except that more virus infection was found in areas where November-April rainfall exceeded $300 \mathrm{~mm}$ than in areas where rainfall was less than $300 \mathrm{~mm}$. In this study, November-April rainfall preceding the growing seasons of 2014-2017 did not exceed $300 \mathrm{~mm}$ in any year in any of the three regions studied. However, there were differences in rainfall among each of the three regions (Table 1).

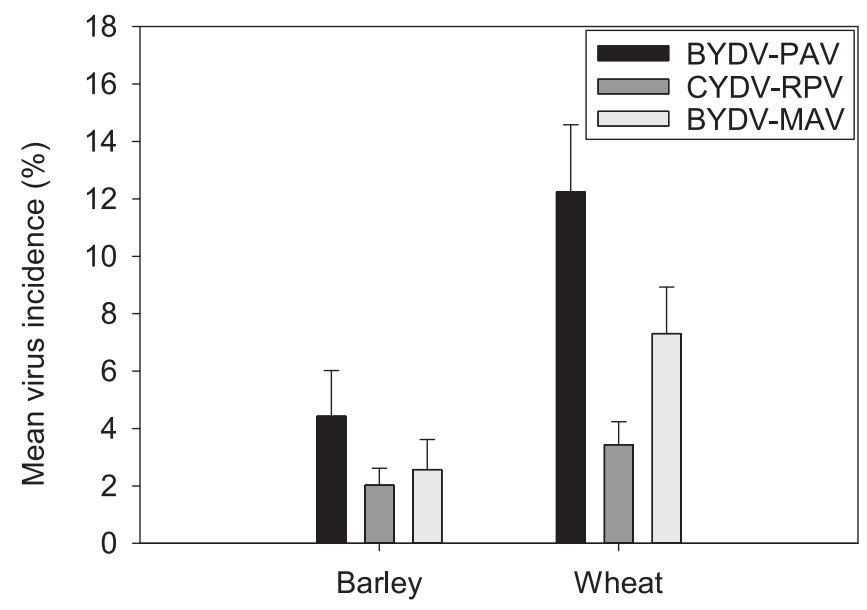

Fig. 5. Mean incidence of BYDV-PAV, CYDV-RPV, and BYDV-MAV in barley $(n=35)$ and wheat $(n=46)$ fields across regions of Victoria during 2014-2017. Error bars represent standard errors of means.
There were also more days with maximum temperature $\geq 36^{\circ} \mathrm{C}$ in the Mallee than in the Wimmera and South West, and this difference is likely to affect aphid populations and activity and therefore virus infection. This demonstrates that the relationship between temperature, rainfall, and YDV infection is complex and that other factors, not captured in this study, also play an important part. Other than
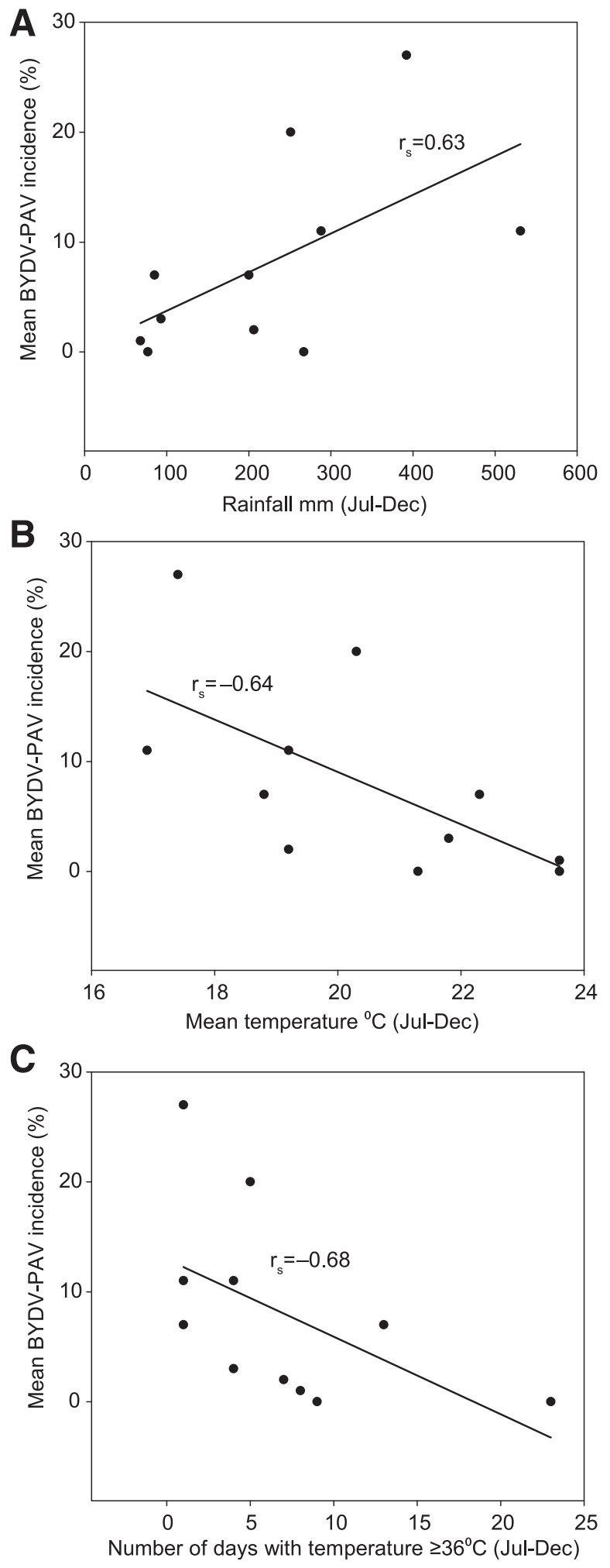

Fig. 6. Relationships between the mean incidence of BYDV-PAV in each region in each year and $\mathbf{A}$, total rainfall; $\mathbf{B}$, mean maximum temperature; and $\mathbf{C}$, number of days with maximum temperature $\geq 36^{\circ} \mathrm{C}$ recorded at the Hopetoun (Mallee), Horsham (Wimmera), and Hamilton (South West) weather stations during July-December in the year preceding the growing season $\left(r_{s}\right.$ indicates the Spearman's rank correlation coefficient). 
the crop type and geographic location, we were unable to collect any further information about the fields that were sampled in this study, so differences in cultivar, spraying, and management practices were not captured; however, these factors are likely to have influenced aphid behavior and activity and YDV infection (Banks et al. 1995; McLean and Khan 1983). However, despite all these factors, there were still reasonable correlations between mean BYDV-PAV incidence and rainfall, temperature, and number of days with maximum temperature $\geq 36^{\circ} \mathrm{C}$ (Fig. 6), further supporting the hypothesis that temperature and rainfall are important factors driving the epidemiology of YDV in western Victoria.

BYDV-PAV was the most commonly detected YDV species in cereals during this 4-year study, and this result is similar to previously published cereal surveys from Australia (Guy et al. 1987; Henry et al. 1992; Jones et al. 1990; Sward and Lister 1987, 1988). However, Milgate et al. (2016) recently reported that CYDV-RPV and BYDVMAV were the most frequently detected YDV species in 2010 and 2014, respectively, in New South Wales. The abundance of a particular YDV species in certain parts of Australia may be influenced by a number of factors, including the presence and activity of alternative vectors (Parry et al. 2012), the types of alternative hosts for both the virus species and aphid vectors, and the susceptibilities of these alternative hosts to the different YDV species and aphid colonization (Guy et al. 1987; Irwin and Thresh 1990; Parry et al. 2012). The intricate relationship between different YDV species and different plant hosts was illustrated in a recent study (Malmstrom et al. 2017) which reported that although infection with either BYDVPAV or CYDV-RPS significantly reduced total biomass in both oats (a crop host) and switchgrass (a noncrop host) when compared with noninfected controls, coinfection with BYDV-PAV and CYDV-RPS resulted in a highly significant reduction of $97 \%$ of total biomass in oats but had no significant effect in switchgrass.

The mean incidence of YDV reported in this study is likely to be an underestimation for two reasons. Firstly, MYDV-RMV, which has also been detected in Victoria (Sward and Lister 1988), was not tested for due to unavailability of MYDV-RMV antiserum. Secondly, mixed infections within individual plants were not recorded in this study, so mean YDV incidence was reported as the maximum recorded value (which was usually BYDV-PAV). Although mixed infections of YDVs have been shown to occur in cereals in Australia (Milgate et al. 2016; Sward and Lister 1988), it is likely that at least some of the CYDV-RPV and BYDV-MAV infections reported in this study were single infections.

In conclusion, this study provides detailed information regarding the prevalence and incidence of BYDV-PAV, CYDV-RPV, and BYDV-MAV in cereal fields, recorded over 4 years across Victoria. These results demonstrate that the changes in virus incidence between regions and years are driven by many factors, but underpinning influences as seen in this study are rainfall and temperature. As yield can be greatly affected by virus outbreaks, information provided in this study will improve our understanding of the epidemiology of YDVs and therefore improve their management.

\section{Acknowledgments}

The authors thank Audrey Delahunty, Connor Cobe, Hollie Riley, and Laura Smith for technical assistance and Susan Robson (DEDJTR) for producing the map of Victoria.

\section{Literature Cited}

ABARES. 2017. Australian crop report (February 2017). Australian Bureau of Agricultural and Resource Economics and Sciences. Canberra, Australia. http://data.daff.gov.au/data/warehouse/aucrpd9abcc003/aucrpd9aba_20170214_ Sn9Dg/AustCropRrt20170214_v1.0.0.pdf

Adams, M. J., Lefkowitz, E. J., King, A. M., et al. 2016. Ratification vote on taxonomic proposals to the International Committee on Taxonomy of Viruses. Arch. Virol. 161:2921-2949.

Banks, P. M., Davidson, J. L., Bariana, H., and Larkin, P. J. 1995. Effects of barley yellow dwarf virus on the yield of winter wheat. Aust. J. Agric. Res. 46:935-946.

Bos, L., and Parlevliet, J. E. 1995. Concepts and terminology on plant/pest relationships: Toward consensus in plant pathology and crop protection. Annu. Rev. Phytopathol. 33:69-102.
Castle, S., Palumbo, J., and Prabhaker, N. 2009. Newer insecticides for plant virus disease management. Virus Res. 141:131-139.

De Barro, P. J. 1991. The ecology of the bird cherry-oat aphid, Rhopalosiphum padi (L.) (Hemiptera: Aphididae) in the low rainfall wheat belt of South Australia. PhD Thesis. The University of Adelaide.

Freeman, A. J., Spackman, M. E., Aftab, M., McQueen, V., King, S., van Leur, J. A. G., Loh, M. H., and Rodoni, B. 2013. Comparison of tissue blot immunoassay and reverse transcription polymerase chain reaction assay for virus-testing pulse crops from a South-Eastern Australia survey. Australas. Plant Pathol. 42:675-683.

Gray, S. M., Power, A. G., Smith, D. M., Seaman, A. J., and Altman, N. S. 1991. Aphid transmission of barley yellow dwarf virus: Acquisition access periods and virus concentration requirements. Phytopathology 81:539-545.

Guy, P. L., Johnstone, G. R., and Morris, D. I. 1987. Barley yellow dwarf virus in, and aphids on, grasses (including cereals) in Tasmania. Aust. J. Agric. Res. 38:139-152.

Hawkes, J. R., and Jones, R. A. C. 2005. Incidence and distribution of Barley yellow dwarf virus and Cereal yellow dwarf virus in over-summering grasses in a Mediterranean-type environment. Aust. J. Agric. Res. 56:257-270.

Henry, M., Francki, R. I. B., and Wallwork, H. 1992. Occurrence of barley yellow dwarf virus in cereals and grasses of the low rainfall wheatbelt of South Australia. Plant Pathol. 41:713-721.

Irwin, M. E., and Thresh, M. J. 1990. Epidemiology of barley yellow dwarf virus: A study in ecological complexity. Annu. Rev. Phytopathol. 28:393-424.

Jiménez-Martínez, E. S., and Bosque-Pérez, N. A. 2004. Variation in barley yellow dwarf virus transmission efficiency by Rhopalosiphum padi (Homoptera: Aphididae) after acquisition from transgenic and nontransformed wheat genotypes. J. Econ. Entomol. 97:1790-1796.

Jones, R. A. C. 2016. Future scenarios for plant virus pathogens as climate change progresses. Adv. Virus Res. 95:87-147.

Jones, R. A. C., McKirdy, S. J., and Shivas, R. G. 1990. Occurrence of barley yellow dwarf viruses in over-summering grasses and cereal crops in Western Australia. Australas. Plant Pathol. 19:90-96.

Luck, J., Spackman, M., Freeman, A., Trębicki, P., Griffiths, W., Finlay, K., and Chakraborty, S. 2011. Climate change and diseases of food crops. Plant Pathol. 60:113-121.

Malmstrom, C. M., Bigelow, P., Trębicki, P., Busch, A. K., Friel, C., Cole, E., Abdel-Azim, H., Phillippo, C., and Alexander, H. 2017. Crop-associated virus reduces the rooting depth of non-crop perennial native grass more than non-crop associated virus with known viral suppressor of RNA silencing (VSR). Virus Res. 241:172-184

McKirdy, S. J., and Jones, R. A. C. 1997. Effect of sowing time on barley yellow dwarf virus infection in wheat: Virus incidence and grain yield losses. Aust. J. Agric. Res. 48:199-206.

McKirdy, S. J., Jones, R. A. C., and Nutter, F. W., Jr. 2002. Quantification of yield losses caused by barley yellow dwarf virus in wheat and oats. Plant Dis. 86:769-773.

McLean, G. D., and Khan, T. N. 1983. Assessing the incidence and severity of barley yellow dwarf virus in the field. Australas. Plant Pathol. 12:50-51.

Milgate, A., Adorada, D., Chambers, G., and Terras, M. 2016. Occurrence of winter cereal viruses in New South Wales, Australia, 2006 to 2014. Plant Dis. 100:313-317.

Miller, W. A., and Rasochová, L. 1997. Barley yellow dwarf viruses. Annu. Rev Phytopathol. 35:167-190.

Murray, G. M., and Brennan, J. P. 2009. Estimating disease losses to the Australian wheat industry. Australas. Plant Pathol. 38:558-570.

Murray, G. M., and Brennan, J. P. 2010. Estimating disease losses to the Australian barley industry. Australas. Plant Pathol. 39:85-96.

Nancarrow, N., Constable, F. E., Finlay, K. J., Freeman, A. J., Rodoni, B. C., Trębicki, P., Vassiliades, S., Yen, A. L., and Luck, J. E. 2014. The effect of elevated temperature on Barley yellow dwarf virus-PAV in wheat. Virus Res. 186:97-103.

Oerke, E.-C. 2006. Crop losses to pests. J. Agric. Sci. 144:31-43.

Parry, H. R., Macfadyen, S., and Kriticos, D. 2012. The geographical distribution of yellow dwarf viruses and their aphid vectors in Australian grasslands and wheat. Australas. Plant Pathol. 41:375-387.

Plumb, R. T. 1983. Barley yellow dwarf virus-a global problem. Pages $185-198$ in: Plant Virus Epidemiology. R. T. Plumb and J. M. Thresh, eds. Blackwell Scientific Publications, Oxford.

Smith, P. R., and Plumb, R. T. 1981. Barley yellow dwarf virus infectivity of cereal aphids trapped at two sites in Victoria. Aust. J. Agric. Res. 32:249-255.

Smith, P. R., and Sward, R. J. 1982. Crop loss assessment studies on the effects of barley yellow dwarf virus in wheat in Victoria. Aust. J. Agric. Res. 33: 179-185.

Strange, R. N., and Scott, P. R. 2005. Plant disease: A threat to global food security. Annu. Rev. Phytopathol. 43:83-116.

Sward, R. J., and Lister, R. M. 1987. The incidence of barley yellow dwarf viruses in wheat in Victoria. Aust. J. Agric. Res. 38:821-828.

Sward, R. J., and Lister, R. M. 1988. The identity of barley yellow dwarf virus isolates in cereals and grasses from mainland Australia. Aust. J. Agric. Res. 39:375-384.

Thackray, D. J., Diggle, A. J., and Jones, R. A. C. 2009. BYDV predictor: A simulation model to predict aphid arrival, epidemics of Barley yellow dwarf 
virus and yield losses in wheat crops in a Mediterranean-type environment. Plant Pathol. 58:186-202.

Trębicki, P., Dáder, D., Vassiliadis, S., and Fereres, A. 2017a. Insect-plant-pathogen interactions as shaped by future climate: Effects on biology, distribution and implications for agriculture. Insect Sci. 24:975-989.

Trębicki, P., Harding, R., Rodoni, B., Baxter, G., and Powell, K. 2010. Vectors and alternative hosts of tobacco yellow dwarf virus in southeastern Australia. Ann. Appl. Biol. 157:13-24.
Trębicki, P., Nancarrow, N., Bosque-Pérez, N. A., Rodoni, B., Aftab, M. Freeman, A., Yen, A., and Fitzgerald, G. J. 2017b. Virus incidence in wheat increases under elevated CO2: A 4-year study of yellow dwarf viruses from a free air carbon dioxide facility. Virus Res. 241:137-144.

Trębicki, P., Nancarrow, N., Cole, E., Bosque-Peréz, N., Constable, F., Freeman, A., Rodoni, B., Yen, A., Luck, J., and Fitzgerald, G. 2015. Virus disease in wheat predicted to increase with a changing climate. Glob. Change Biol. 21: 3511-3519. 